Petar Vuković

Uniwersytet w Zagrzebiu

petar.vukovic@ffzg.hr
Data przesłania tekstu do redakcji: 30.06 .2013

Data przyjęcia tekstu do druku: 11.08.2013

\title{
Buniewcy z Bački - język i tożsamość
}

\begin{abstract}
Vuković Petar, Buniewcy z Bački-język i tożsamość (Bunjevci from Bačka - Language and Identity). „Poznańskie Studia Slawistyczne” 8. Poznań 2015. Publishing House of the Poznań Society for the Advancement of the Arts and Sciences, pp. 239-256. ISSN 2084-3011.

Bunjevci from the region of Bačka are a deeply divided community: some of them believe they are a separate ethnic group with a distinct language, while others claim they are a subgroup of Croats and speak a Croatian dialect. The paper explains historical roots of the group's divided ethnic consciousness and explores its consequences on the construction of their contemporary identities. First, the formation of Bunjevci as a pre-modern ethnicity in Dalmatia is discussed. It is followed by an account of historical experiences of those of them who later migrated to the Danube region in Hungary. The paper is concluded by a comparison between the Bunjevci's two models of language regulation and politics of memory.
\end{abstract}

KeYwords: Bunjevci; Bačka, ethnic group; ethnic identity; cultural identity; language usage

\section{Wstęp}

Na krótko przed spisem powszechnym w Serbii w 1991 roku do statystyk demograficznych wprowadzono nową kategorię etniczną Buniewców. W ramach tego spisu oraz kolejnych z lat 2002 i 2011 zarejestrowano dwadzieścia tysięcy osób, które zadeklarowały przynależność do tej grupy etnicznej. Większość z nich pochodziła z północnej Bački, czyli z okolic Suboticy i Somboru ${ }^{1}$. Nowa, oficjalnie uznana wspólnota

${ }^{*}$ Chorwacka wersja tekstu: P. Vuković, Bački Bunjevci i otpor modernizaciji, w: Otpor. Subverzivne prakse u hrvatskome jeziku, književnosti i kulturi. Zbornik radova 42. seminara Zagrebačke slavističke škole, red. T. Pišković, T. Vuković, Zagreb 2014, s. 197-201.

${ }^{1}$ Bačka to region geograficzny i historyczny, którego granice na zachodzie i południu wyznacza Dunaj, a na wschodzie Cisa. Do końca I wojny światowej należała w całości do Królestwa Węgier, w którego skład po roku 1920 wchodziły tylko jej północne krańce. Większa część Bački znalazła się w granicach nowo powstałego państwa południowosłowiańskiego, obecnie zaś należy do Serbii. Buniewcy zamieszkiwali węgierskie tereny naddunajskie (ugarsko Podunavlje), ale ich osad najwięcej było właśnie w północnej Bačce - w okolicach 
zaczęła egzekwować swoje prawa po roku 2002, czyli po uchwaleniu w Serbii nowej ustawy o mniejszościach narodowych. Na jej podstawie w 2003 roku powołano Radę Narodową Buniewskiej Mniejszości Narodowej (Nacionalni savet bunjevačke nacionalne manjine), która rok później zwróciła się do władz państwowych o uznanie buniewskiego za odrębny język i tym samym możliwość posługiwania się nim w mediach publicznych oraz instytucjach oświatowych. W 2005 roku regionalny ośrodek telewizji serbskiej wyemitował pierwsze programy w języku buniewskim, a dwa lata później do kilku szkół podstawowych w Suboticy i Somborze wprowadzono fakultatywny przedmiot o nazwie gwara buniewska z elementami kultury narodowej (Bunjevački govor s elementima nacionalne kulture $)^{2}$.

Uznanie Buniewców za mniejszość narodową oraz zastosowanie języka buniewskiego w niektórych dziedzinach komunikowania publicznego w Serbii pokrywa się z szerszymi procesami glokalizacyjnymi, których przejawem jest m.in. wzrost świadomości o potrzebie ochrony praw wspólnot etnicznych, takich jak prawo do posługiwania się własnym językiem oraz do zachowania dziedzictwa kulturowego. Wielu Buniewców z Bački nie wierzy jednak, że uznanie ich w Serbii za mniejszość narodową, a języka buniewskiego za odrębny, bierze się z troski o ich prawa. To część uważająca się za Chorwatów, która nadanie Buniewcom rangi samodzielnej wspólnoty etnicznej tłumaczy dążeniem władz serbskich do podzielenia i osłabienia tamtejszej mniejszości chorwackiej ${ }^{3}$.

Suboticy i Somboru w dzisiejszej Serbii oraz wokół miasta Baja, leżącego na terenie Węgier. Tam też zamieszkują do dziś.

${ }^{2}$ Po dyskusji dotyczącej tego, czy wariant, którym posługują się Buniewcy z Bački, jest odrębnym językiem, czy też dialektem (brali w niej udział m.in. przedstawiciele Akademii Nauki i Sztuki z Wojwodiny, Serbii i Chorwacji) do nazwy przedmiotu szkolnego wprowadzono neutralny termin govor (gwara) (Vuković 2007: 699-701).

${ }^{3}$ Wraz z kategorią etniczną Buniewców do statystyk demograficznych w Serbii wprowadzono także Šokców (Šokci). Podczas spisu powszechnego propaganda medialna usiłowała zniechęcić członków tych wspólnot do deklarowania przynależności do narodowości chorwackiej. Większość Šokców zamieszkujących zachodnią Bačkę tę sugestię jednak odrzuciła. Na terenach wokół Suboticy - na których liczba Chorwatów niebędących Buniewcami jest znikoma - zarejestrowano wtedy 16282 Chorwatów i 17527 Buniewców. W Somborze odnotowano 8699 Chorwatów i 2966 Buniewców, tam jednak część Chorwatów jest šokackiego pochodzenia. 
W niniejszym artykule ukazane zostaną historyczne korzenie polaryzacji świadomości etnicznej Buniewców z Bački oraz jej wpływ na wybór treści kulturowych, konstytuujących dziś tożsamość/tożsamości członków omawianej wspólnoty. Wychodzę od przypomnienia fazy formowania się Buniewców jako przednowoczesnej etni w Dalmacji oraz jej późniejszego rozwoju w Lice i na Chorwackim Przymorzu. Następnie omawiam historyczne doświadczenia Buniewców, którzy z Dalmacji migrowali na węgierskie tereny naddunajskie. Końcową część artykułu poświęcam współczesnym uregulowaniom kwestii językowych oraz kulturze pamięci obu grup Buniewców z Bački - tych, którzy uważają się za Chorwatów oraz tych, którzy tę przynależność narodową odrzucają.

\section{Wołoskie korzenie}

Buniewcy z Bački są obecnie największą i najbardziej znaną, choć nie jedyną, grupą buniewską. Członkowie tej wspólnoty zamieszkują również okolice Senja na Chorwackim Przymorzu, tak dalece jednak zintegrowali się tam z narodem chorwackim, że ich poczucie odrębności etnokulturowej jest wyjątkowo słabe. Obie buniewskie grupy łączy posługiwanie się nowosztokawskim dialektem ikawskim, przynależność do Kościoła rzymskokatolickiego oraz wciąż żywe dziedzictwo dynarskiej kultury ludowej. Te wspólne cechy zostały uformowane w ich dalmatyńskiej kolebce, gdzie we wczesnej nowożytności rozpoczęło się formowanie Buniewców jako przednowoczesnej etni, co - jak pokazują nowsze badania historyczne (Šarić 2008; 2010) odbywało się w ramach etnicznej dynamiki tamtejszych Wołochów ${ }^{4}$.

Wołochami nazywano początkowo starszą romańską lub zromanizowaną ludność Półwyspu Bałkańskiego, która po przybyciu Słowian wycofała się na tereny górskie ${ }^{5}$. Wołosi żyli tam półkoczowniczo w rozszerzo-

${ }^{4} \mathrm{~W}$ polskich publikacjach spotykane są formy: Vlach/Vlah i Wołoch. Redakcja przyjmuje polską wersję Wołoch, pozostawiając termin Vlah w objaśnieniach historycznojęzykowych (przyp. red.).

${ }^{5}$ Nazwa Wołoch/Vlah pochodzi od pragermańskiego *wahlaz 'obcy'. Słowem tym Germanie określali na początku wszystkich Celtów (stąd nazwa Wales), później zaś tylko Celtów zromanizowanych (stąd Walonia). Następnie wyraz w formie * volxъ przejęli Słowianie i określali nim posługującą się wariantami języków romańskich ludność, z którą mieli kontakt. 
nych rodzinach, komunach (tzw. katuny) i zajmowali się przede wszystkim hodowlą bydła. W średniowiecznych państwach południowosłowiańskich cieszyli się szczególnym statusem, który zachowali również w imperium osmańskim. Migrowali często i masowo oraz zaciągali się do wojsk rozmaitych imperialnych władców. Nie znali pisma, dlatego wiadomości o nich czerpiemy ze źródeł historycznych innych ludów.

Choć długo zachowali swą patriarchalną kulturę pasterską, przejmowali stopniowo język słowiańskich sąsiadów. Jak się wydaje, proces zamiany języka był szczególnie intensywny w Hercegowinie pod koniec XIV wieku, kiedy powstawały dialekty nowosztokawskie ${ }^{6}$. Ich ekspansję zawdzięczamy właśnie językowo zeslawizowanym Wołochom, którzy migrując, przenosili je na inne ziemie. Z czasem nazwa Vlah na terenach chorwackich przestała oznaczać użytkowników gwar romańskich. W południowej i środkowej Dalmacji określano tak ludność pochodzącą z głębi kraju i wyróżniającą się dynarskim rysem kulturowym, na obszarach kajkawszczyzny niekiedy nazywano w ten sposób osoby mówiące w dialektach nowosztokawskich, w Lice zaś i północnej Dalmacji - w których większość Wołochów była prawosławna - prawosławnych. W części Dalmacji pozostającej pod panowaniem weneckim zamiast nazwy Vlah używano określenia Morlak ${ }^{7}$. Ostatnimi potomkami niezeslawizowanych Wołochów w Chorwacji są Istrorumuni.

Nazwa Bunjevac rozprzestrzeniła się pod koniec XVI wieku wśród Wołochów w Dalmacji kontynentalnej, dokąd przybyli z Hercegowiny. Społeczność wołoska, dla której przynależność religijna nie była początkowo istotna, z czasem - w rezultacie odnowienia serbskiego patriarchatu w Peci w roku 1557 oraz zapoczątkowanej przez sobór trydencki reformy Kościoła katolickiego - zaczęła dzielić się na prawosławnych i kato-

${ }^{6} \mathrm{~W}$ centralnej części obszaru południowosłowiańskiego posługiwano się początkowo dwoma dialektami sztokawskimi: wschodnim i zachodnim. Ich przenikanie się w XIV wieku na terenie Hercegowiny doprowadziło do pojawienia się wspólnych innowacji językowych. Konwergentny rozwój dwóch wariantów doprowadził do powstania dialektów nowosztokawskich, których zasięg z czasem rozszerzył się na kolejne tereny. Spośród współczesnych dialektów starosztokawskich od zachodniosztokawskiego pochodzą dialekty slawoński (którym mówią Šokcy) i wschodniobośniacki, a od wschodniego zecko-sandżacki i kosowsko-resawski.

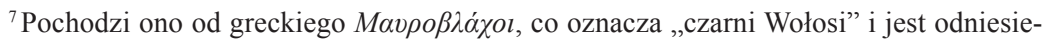
niem do koloru tradycyjnego stroju wołoskiego. 
lików. Po wprowadzeniu w 1582 roku przez Kościół katolicki kalendarza gregoriańskiego różnice między prawosławnymi a katolikami stały się widoczne nawet na poziomie życia codziennego. Wówczas wśród Wołochów pojawiły się nazwy, którymi wyznawcy dwóch religii określali się nawzajem: neutralnie prawosławnego nazwano ristjanin, a katolika krstjanin, obraźliwym zaś określeniem prawosławnego było słowo $R k a c^{8}$, a katolika - Bunjevac. Prawosławni Wołosi szybko zintegrowali się z Serbami, wyznawanie bowiem prawosławia w zachodniej części Półwyspu Bałkańskiego zostało utożsamione z przynależnością do narodu serbskiego. Wołosi wyznania katolickiego natomiast zjednoczyli się z nowoczesnym narodem chorwackim, choć proces ten przebiegał wolniej i był bardziej skomplikowany z tego względu, że Kościół katolicki ma charakter ponadnarodowy. To jego instytucje odegrały jednak kluczową rolę w procesie homogenizacji ludności katolickiej w centralnej części obszaru południowosłowiańskiego.

Deprecjonująca konotacja, którą na początku zawierała nazwa Bunje$v a c$, zanikła prawdopodobnie jeszcze w Dalmacji. Migrując na nowe tereny (do Liki, na Chorwackie Przymorze, do Gorskiego Kotaru i na węgierskie tereny naddunajskie), Buniewcy przenieśli swój etnonim wraz z nowym thumaczeniem, mówiącym o ich pochodzeniu znad Buny ${ }^{9}$. Rzeka ta ma swoje źródło we wschodniej Hercegowinie, gdzie już w XV wieku mówiło się (i)jekawską nowosztokawszczyzną. Buniewcy natomiast posługują się wariantem ikawskim, w związku z tym jest bardziej prawdopodobne, że wywodzą się jednak z terenów zachodniej Hercegowiny. Możliwe, że legendę o Bunie rozpowszechnili franciszkanie w czasach konfliktu z biskupami dalmatyńskimi, dotyczącego sprawowania zwierzchnictwa nad Wołochami w Dalmacji. Hydronim Buna i etnonim Bunjevac są formalnie podobne, w dodatku nad rzeką Buną leży Blagaj - miasto, w którym rządził legendarny książę Stefan (Herceg Stjepan). Buna posłużyła jako metonimiczne określenie Hercegowiny, na co powoływali się franciszkanie, twierdząc, że Buniewcy pochodzą z terenów podlegających ich jurysdykcji, więc sprawowanie duszpasterstwa nad Buniewcami należy do nich

${ }^{8} \mathrm{O}$ nazwie Rkać cf. Andrić 1988.

${ }^{9}$ Jako pierwszy odnotował je Alberto Fortis w angielskim wydaniu swojej Podróży po Dalmacji (Travels into Dalmatia) z 1778 roku (Šarić 2010: 182). 
nawet na obszarze, który administracyjnie jest częścią Kościoła dalmatyńskiego $^{10}$ (Šarić 2010: 184-185).

Bez wątpienia legenda o Bunie wpłynęła na szerzenie się i umacnianie etnonimu Bunjevac, ale jego genezy należy szukać gdzie indziej ${ }^{11}$. W świetle nowszych, wspomnianych już badań historycznych na pierwszy plan ponownie wysuwają się teorie wiążące go z romańską warstwą językową. Wyprowadzają one nazwę Bunjevac od wołoskiego imienia Bun/Bunj, które wywodzi się od łacińskiego Bonifacius ${ }^{12}$. Jej struktura słowotwórcza wskazuje na znaczenie dzierżawczości i pochodzenia, z czego możemy wnioskować, że początkowo odnosiła się prawdopodobnie do członków jednego z wołoskich katunów, czyli rozszerzonej rodziny ze wspólnym przodkiem, od którego została nazwana. Określenia tego typu były stosunkowo częste wśród dynarskich Wołochów (np. Đuraševci, Gleđevci, Maleševci $\mathrm{i}$ in.), a w dalmatyńskiej onomastyce i toponomastyce rozpowszechniły się w wieku XVI, prawdopodobnie na skutek wczesnonowożytnych migracji wołoskich (Šarić 2010: 186-190). Wydaje się zatem, że nazwa Bunjevac kilkakrotnie zmieniała zakres semantyczny: najpierw oznaczała członków wołoskiego katunu, następnie stała się pejoratywnym określeniem Wołochów katolików, a w końcu etnonimem, który miał wskazywać miejsce pochodzenia.

Nazwa zachowała się później przede wszystkim w przekazie ustnym, podczas gdy władze świeckie i kościelne rzadko się nią posługiwały. Nawet franciszkanie przestali wyodrębniać Buniewców od pozostałych południowosłowiańskich katolików, określając ich wspólnym mianem Iliri (Ilirowie) lub Slovinci (Słowianie). Jedynym wyjątkiem była diecezja

${ }^{10}$ Podczas gdy na terytorium weneckim Kościół katolicki zorganizowany był diecezjalnie, na terytorium znajdującym się pod panowaniem tureckim nie było władzy biskupiej. Jedynymi duchownymi katolickimi, którzy mogli działać na tych terenach, byli franciszkanie, a ich prowincja zakonna Bośnia Srebrna (Bosna Srebrena) we wczesnych czasach nowożytnych poza Bośnią obejmowała również dużą część Dalmacji, Slawonii i południową część Królestwa Węgier.

${ }^{11} \mathrm{O}$ pochodzeniu nazwy Buniewac cf. Bačić et al. 2005.

${ }^{12}$ Źródła historyczne z XIII i XIV wieku wskazują, że Wołosi w tym czasie używają jeszcze imion romańskich, ale już od wieku XV przeważają imiona słowiańskie, np. Miloš, Stojan, Radovan, Vuk (Šarić 2010: 187-188), które od XVII wieku wśród katolickich Wołochów stopniowo wypierane są przez imiona zachodniochrześcijańskie, a w północnej Dalmacji i Lice zaczynają być z czasem odbierane jako prawosławne, tzn. serbskie. 
senjsko-modruška, w której nazwa Bunjevac została wprowadzona do oficjalnego użytku. Na tym terenie, znajdującym się pod panowaniem Habsburgów, większość ludności wołoskiej była prawosławna. W celu oddzielenia Wołochów katolików od prawosławnych oraz zbliżenia ich do innych mieszkających tu katolików - autochtonicznej ludności chorwackiej i osiedlonych Kraińców (Kranjci) - uprzedzonych do wołoskiej „dzikości”, senjscy biskupi pod koniec XVII wieku sięgnęli po ludową nazwę Bunjevac. Wsparli tym samym proces akulturacji Buniewców z pozostałą ludnością katolicką, zakończony na początku wieku XIX ich integracją z nowoczesnym narodem chorwackim ${ }^{13}$. Świadomość wołoskiego pochodzenia wśród Buniewców się nie zachowała (podobnie zresztą jak wśród dalmatyńskich i zachodnioslawońskich Serbów).

\section{Buniewcy na węgierskich terenach naddunajskich}

Najwcześniejsze wędrówki Wołochów na tereny naddunajskie odbyły się prawdopodobnie w pierwszej połowie XVI wieku, jednak zdecydowanie najliczniejsze miały miejsce w wieku XVII. Świadectwem ich pierwszej wielkiej fali jest, datowany na rok 1608, list księcia (kneza) szybenickiego, w którym informuje senat wenecki o przesiedleniu dwóch tysięcy rodzin morlackich z okolic Szybenika na tereny naddunajskie. Pierwsza wzmianka o Buniewcach na tym obszarze pojawiła się w 1622 roku w liście, w którym franciszkanin Šimun Matković prosił Kongregację Rozkrzewiania Wiary o zgodę na sprawowanie posługi duszpasterskiej w parafii Bunjevci, będącej pod zwierzchnictwem arcybiskupa Kalocsy. Do drugiej dużej fali migracji Buniewców doszło około roku 1690, za czasów V wojny austriacko-tureckiej. Z tym rdzeniem wspólnoty buniewskiej stopiły się później również inne, mniejsze grupy o różnym

\footnotetext{
${ }^{13}$ Proces ten można prześledzić na przykładzie rodziny Starčeviciów z miejscowości Veliki Žitnik. Podczas gdy pod koniec XVII wieku Miloš Starčević był jeszcze określany jako „katolicki Wołoch lub Buniewac” i wyraźnie odróżniał się od autochtonicznych Chorwatów, jego potomek Ante Starčević na początku wieku XIX stał się twórcą nowoczesnej chorwackiej ideologii narodowej (Šarić 2008: 32). Poza rodziną Starčeviciów znana jest również, pochodząca z Liki i Przymorza, buniewska rodzina Paveliciów, z której wywodził się przywódca ustaszy, Ante Pavelić.
} 
pochodzeniu ${ }^{14}$. Półkoczownicza kultura pasterska Buniewców w nowym miejscu przekształciła się w osiadłą kulturę rolniczą, ale wiele elementów patriarchalnej kultury dynarskiej zachowało się do dziś. Spośród nich najlepiej zbadane zostały obyczaje ślubne (Černelić 1995-1996). Zachowała się również nazwa Buniewcy i to przede wszystkim w przekazach ustnych, w źródłach historycznych początkowo pojawiając się rzadko.

Węgierskie władze terytorialne stosowały wobec Buniewców termin Rasciani Catholici, czyli katolicy Raszanie ${ }^{15}$, podczas gdy buniewska szlachta w swych księgach genealogicznych posługiwała się nazwą Dalmatyńczycy. Franciszkanie natomiast, jak już wspomnieliśmy, używali określeń Iliri lub Slovinci. Dzięki franciszkanom Buniewcy zamieszkujący tereny Królestwa Węgierskiego poprzez wspólną tradycję piśmienniczą byli powiązani z katolikami w Slawonii, Bośni i Dalmacji (Skenderović 2011). Co więcej, językiem tego piśmiennictwa był właśnie ich dialekt, czyli nowosztokawska ikawica (Pranjković 2000). Związki te uległy jednak osłabieniu po podpisaniu pokoju w Karłowicach w roku 1699. Franciszkańska prowincja zakonna Bośnia Srebrna została wkrótce podzielona na trzy mniejsze (dalmatyńską, bośniacką i slawońsko-węgierską), co znacznie ograniczyło mobilność franciszkanów oraz obieg ich tekstów. Jednocześnie, w ramach odnowy ustroju diecezjalnego w Królestwie Węgierskim, franciszkańskich zakonników zastąpili księża diecezjalni, którzy nie tylko nie utrzymywali kontaktów z Ilirami, ale często też nie mówili w ich języku.

Drogę od przekazu ustnego do oficjalnego dyskursu nazwa Bunjevac utorowała sobie w czasach odrodzenia narodowego. W roku 1868 w Królestwie Węgierskim uchwalono ustawę o mniejszościach narodowych, a dwa lata później biskup Ivan Antunović w Kalocsy rozpoczął wydawanie czasopisma „Bunjevačke i šokačke novine”. Wychodziły w języku zagrzebskiej

\footnotetext{
${ }^{14}$ Duża buniewska rodzina Skenderoviciów ma prawdopodobnie korzenie albańskie, natomiast równie znana rodzina Duliciów - bośniacko-muzułmańskie.

${ }^{15}$ Nazwa Raszanin (Rašanin) związana jest z Raszką, średniowiecznym państwem serbskim, ale w źródłach węgierskich jej znaczenie jest rozszerzone i dotyczy również pozostałych imigrantów ze słowiańskiego południa. Serbscy autorzy tymczasem niezmiennie tłumaczą nazwę Rasciani Catholici jako „Serbowie katolicy”. W serbskiej nauce dominuje pogląd, że Buniewcy są Serbami lub przynajmniej mają serbskie korzenie. Teza ta pojawia się zarówno w najstarszych (np. Ivanić 1894; Erdeljanović 1930), jak i najnowszych opracowaniach (np. Gavrilović 2007; Petrović 2007).
} 
szkoły filologicznej, tzn. standardowym języku chorwackim drugiej połowy XIX wieku, a główni współpracownicy uważali, że w tym języku powinny być również publikowane książki przeznaczone dla buniewskich szkół. Twierdzili, że podręczników nie należy pisać „stylem kulinarnym”, lecz rozwiniętym językiem standardowym oraz nie dla każdej ,garstki ludzi” i jej dialektem, lecz językiem większej populacji (Vuković 2010: 284). W trakcie tej dyskusji Stipan Vujević, Buniewac z Bački, po raz pierwszy określił swój język jako chorwacki, a Ivan Antunović w dziele Rasprava o podunavskih i potisanskih Bunjevcih $i$ Šokcih z 1882 roku pozostawia pierwsze świadectwo, że Buniewcy węgierscy zaczęli nazywać się Chorwatami w nowoczesnym znaczeniu tego słowa (Vuković 2010: 286).

Projekt Antunovicia położył podwaliny pod integrację Buniewców (i Šokców) z nowoczesnym narodem chorwackim, zakończył się jednak niepowodzeniem - czasopismo przestało się ukazywać już w 1872 roku (do 1876 wydawano jeszcze dodatek kulturalny „Bunjevačka i šokačka vila”), a podręczniki szkolne nigdy nie ujrzały światła dziennego. Ze względu na ogólną sytuację w Królestwie Węgierskim w praktyce rzadko postępowano zgodnie z liberalną ustawą o mniejszościach, a samą wspólnotę buniewską dzieliła kwestia celów ruchu narodowego. Wielu Buniewców było węgierskimi lojalistami, co sprawiało, że „budzenie narodowości” rodziło ich skrajną podejrzliwość. Dotyczyło to szczególnie szlachty i bogatego mieszczaństwa, które w drugiej połowie XIX wieku w największym stopniu zintegrowały się z nowoczesnym narodem węgierskim (jak np. magnackie rodziny Rudiciów i Vojniciów) ${ }^{16}$. Do niektórych trafiła również ideologia językowej serbskości Vuka Karadžicia, zgodnie z którą wszyscy posługujący się dialektem sztokawskim - a więc i Buniewcy - są Serbami (jej zwolennikiem był m.in. prawnik i leksykograf Ambrozije Šarčević). Buniewców uważających się za Serbów było wprawdzie niewielu, ale odrzucający przynależność do narodu chorwackiego od tej pory poparcia szukali właśnie w kręgach wielkoserbskich ${ }^{17}$.

${ }^{16}$ Por. Weaver (2011), który opisuje, że Węgrzy także uważali Buniewców za lojalnych obywateli, w odróżnieniu od Serbów zamieszkujących południową część Królestwa Węgier oraz Chorwatów z Chorwacji i Slawonii.

${ }^{17}$ Było to widoczne także podczas wojny po rozpadzie Jugosławii, kiedy w 1993 roku, na łamach wznowionego czasopisma „Bunjevačke i šokačke novine”, działacze polityczni Buniewców nie-Chorwatów podkreślali swoją lojalność wobec polityki Slobodana Miloševicia. 
Sytuacja zmieniła się znacznie po I wojnie światowej, kiedy Bačka została podzielona między Węgry i nowe państwo południowosłowiańskie. Polityczne i kulturalne życie Buniewców zaczęło koncentrować się wtedy na południu, podczas gdy na Węgrzech byli poddawani systematycznym represjom. Wielu $\mathrm{z}$ nich przeniosło się $\mathrm{z}$ tego powodu do południowej części Bački, jak np. historyk Petar Pekić ${ }^{18}$. I choć wśród niezmadziaryzowanych Buniewców obóz prowęgierski już wtedy nie istniał, buniewska wspólnota pozostała głęboko podzielona. Z jednej strony, Buniewcy z Bački mocniej niż kiedykolwiek związali się z chorwackimi ośrodkami kulturalnymi - główną rolę odegrał Kościół katolicki, istotna była też działalność Chorwackiej Partii Chłopskiej (Hrvatska seljačka stranka) (Bara 2006). Z drugiej strony, wprowadzona przez Belgrad oficjalna zasada unitaryzmu usiłowała powstrzymać ich dalszą integrację z narodem chorwackim (Černelić 2006), za czym opowiadali się również niektórzy znani Buniewcy, jak pisarka Mara Đorđević Malagurska.

Po II wojnie światowej władze komunistyczne odcięły się od międzywojennej polityki unitaryzmu i głosiły oficjalne stanowisko, zgodnie z którym nie wolno już było zaprzeczać chorwackości Buniewców ${ }^{19}$. W wyniku tej zmiany w Suboticy zainicjowano wydawanie prasy w języku chorwackim oraz działalność Chorwackiego Teatru Narodowego (Hrvatsko narodno kazalište), a w szkołach utworzono osobne chorwackie klasy. Praktyki te porzucono po podpisaniu umowy nowosadzkiej w roku 1954, przesądzającej m.in. o wyłącznym użyciu w Serbii „wymowy ekawskiej” (tzn. serbskiego standardu językowego), a w Chorwacji „wymowy ijekawskiej”

Widać to również dzisiaj, gdy obecny prezydent Serbii, Tomislav Nikolić, mówi o Buniewcach jako ,autochtonicznym narodzie południowosłowiańskim”; cf. <http://www.seebiz.eu/ nikolic-porucio-bunjevcima-niste-ni-hrvati-ni-srbi/ar-77197/>, 1.12.2013.

${ }^{18}$ Buniewcy na Węgrzech obecnie są zasadniczo węgierskojęzyczni, a ich tradycyjne gwary można usłyszeć niezwykle rzadko. Mimo to w 2006 roku również tam pojawiła się inicjatywa, by uznać Buniewców za odrębną wspólnotę etniczną. Na podstawie opinii wydanej przez Węgierską Akademię Nauk, według której Buniewcy są jedną z grup narodu chorwackiego, węgierski parlament wniosek odrzucił. Podobnie było z kolejną inicjatywą w 2010 roku - cf. Drugo mišljenje 2011. Przy okazji warto wspomnieć, że z miasteczkiem Katymár w węgierskiej części Bački związana jest buniewska rodzina o nazwisku Matoš. Tam też urodził się dziadek poety Antuna Gustava.

${ }^{19}$ Działacze polityczni Buniewców nie-Chorwatów oraz liczni serbscy autorzy politykę tę uznają za manifestację komunistycznego totalitaryzmu (Njegomir 2008). 
(tzn. chorwackiego standardu językowego). W latach pięćdziesiątych XX wieku rozpoczął się również intensywny proces zanikania buniewskiej ikawicy. Obecnie większość serbskich Buniewców w komunikowaniu publicznym, a najczęściej także i prywatnym, posługuje się serbskim językiem standardowym, ikawica zaś używana jest jedynie w kilku wsiach w okolicach Suboticy.

Po upadku komunizmu polityczni i kulturalni działacze Chorwatów wojwodinskich dążyli do tego, by także ich wspólnocie przyznano prawa, które inne mniejszości w Wojwodinie miały już od dawna. W prowincji mieszka kilka chorwackich społeczności, spośród których największą i najbardziej aktywną byli Buniewcy, dlatego też Subotica szybko stała się najważniejszym ośrodkiem wspólnoty chorwackiej w Serbii. W 1993 roku chorwacki uzyskał tam status jednego z języków urzędowych, pięć lat później w lokalnej stacji radiowej wznowiono chorwacki program, a w 2002 roku w szkołach podstawowych utworzono pierwsze klasy, w których lekcje w całości odbywają się po chorwacku. W Suboticy znajdują się obecnie siedziby najważniejszych instytucji Chorwatów w Serbii: Demokratyczny Związek Chorwatów w Wojwodinie (Demokratski savez Hrvata u Vojvodini), Chorwacka Rada Narodowa (Hrvatsko nacionalno vijeće) oraz Instytut Kultury Chorwatów Wojwodinskich (Zavod za kulturu vojvođanskih Hrvata). Śladami Buniewców Chorwatów podążyli wkrótce Buniewcy nie-Chorwaci, którzy również stworzyli swoje instytucje i sformułowali żądania jako mniejszość narodowa

\section{Kulturowe treści tożsamości}

Mówiąc o wartościach kulturowych, konstytuujących dziś ich tożsamość/tożsamości, obie grupy Buniewców z Bački napotykają podobne problemy. I jedni i drudzy posługują się głównie językiem serbskim, który prawie całkowicie wyparł buniewską ikawicę, natomiast chorwacki standard nie zdołał się umocnić. Buniewcy nie posiadali dotąd stabilnych instytucji, które zajmowałyby się pielęgnowaniem tradycji, dlatego ich kanon kulturowy jest niezdefiniowany i w wielu kwestiach płynny. Instytucje utworzone po upadku komunizmu, w obu grupach koncentrują się na uregulowaniu kwestii językowych oraz wyborze elementów tradycji 
kulturowej, wokół których mogłaby skrystalizować się kolektywna tożsamość. Odbywa się to za pomocą dwu zupełnie różnych modeli.

Buniewcy Chorwaci są zaangażowani w krzewienie chorwackiego języka standardowego, którego systemowe nauczanie rozpoczęto w szkołach podstawowych i średnich. By móc odnowić pozrywaną nić wspólnotowej pamięci historycznej, ich instytucje wspierają multidyscyplinarne podejście w badaniach nad problematyką buniewską. Wśród nich wyróżniają się Chorwackie Towarzystwo Akademickie (Hrvatsko akademsko društvo) z projektem Leksikon podunavskih Hrvata - Bunjevaca i Šokaca (publikowanym od 2004 roku; do tej pory ukazało się 12 tomów) oraz wymieniony wyżej Instytut Kultury Chorwatów Wojwodińskich, wydający czasopismo „Godišnjak za znanstvena istraživanja” (wychodzi od 2009 roku; do tej pory ukazały się 4 numery ${ }^{20}$ ). Większość autorów obu publikacji ciągłych to członkowie wspólnoty, wielu z nich pracuje w instytucjach naukowych w Chorwacji. Należy wspomnieć, że w 2008 roku Chorwackie Towarzystwo Akademickie, wraz z Chorwackim Instytutem Historycznym (Hrvatski institut za povijest), zorganizowało w Zagrzebiu konferencję pt. „Tożsamość Chorwatów z Bački”, po której ukazał się tom z wystąpieniami (Identitet bačkih Hrvata 2010).

Ważnym aspektem polityki pamięci Buniewców Chorwatów jest pielęgnowanie szczególnych cech etnokulturowych, rozumianych jednak jako elementy mozaiki tradycji chorwackich, co widać w podejściu zarówno do literatury dialektalnej (Vuković 2011), jak i kultury ludowej i folkloru. Szczególna uwaga skierowana została na wspieranie posługiwania się buniewską ikawicą, przynajmniej w niektórych dziedzinach komunikowania publicznego, lecz bez aspiracji do przejęcia roli języka standardowego. W beletrystyce pojawia się ona jako element stylizacji (np. w dramatach Matiji Poljakovicia i prozie Petka Vojnicia Purčara) lub medium podstawowe (np. w poezji Vojislava Sekelja), stosowana jest również w felietonach prasowych, muzyce (tamburaška glazba) i literaturze popularnej ( $p u$ čka književnost). W podtekście posługiwania się nowosztokawską ikawicą leży przekonanie, że to - największy pod względem liczby użytkowników i zasięgu terytorialnego - dialekt chorwacki, na którym ponadto w XVIII wieku opierał się główny język chorwackiego piśmiennictwa.

${ }^{20}<$ http://godisnjak.zkvh.org.rs/>, 26.06.2013. 
Również Buniewcy nie-Chorwaci definiują kulturowe treści swojej tożsamości w sposób instytucjonalny ${ }^{21}$. Wprowadzają język buniewski do niektórych dziedzin komunikowania publicznego, mimo że nie ma deskryptywnych bądź preskryptywnych słowników ani podręczników do jego nauki, a wspomniany na początku przedmiot szkolny - gwara buniewska z elementami kultury narodowej poświęcony jest raczej szerzeniu wiedzy z zakresu literatury ustnej, sztuki i obyczajów ludowych oraz tradycyjnych rzemiosł, niż nauczaniu języka. Rada Narodowa Buniewskiej Mniejszości Narodowej we współpracy z Serbską Akademią Nauki i Sztuki zorganizowała dwie konferencje naukowe poświęcone dziedzictwu kulturowemu Buniewców, po których ukazały się tomy Zbornik radova sa simpozijuma „O Bunjevcima” (2007, pod redakcją Dušana Čampraga) oraz Etnolingvistička i istorijska istraživanja o Bunjevcima (2008, pod redakcją Mata Pižuricy i Suzany Kujundžić-Ostojić), a w 2012 roku zainicjowano wydawanie czasopisma „Bunjevački prigled”22. Większość autorów tych publikacji to Serbowie, zwolennicy tezy o serbskim pochodzeniu Buniewców. Stosunek działaczy politycznych i kulturalnych Buniewców nie-Chorwatów do ich własnego dziedzictwa kulturowego bardziej niż wspomniane tomy pokonferencyjne wyrażają dwa teksty programowe, dotyczące buniewskiego języka i literatury.

Jedynym w miarę spójnym tekstem opisującym język buniewski jest Kako pisat bunjevački? ${ }^{23}$ (Vuković 2014). Jednoznacznie krytycznie autor odnosi się do jego współczesnego stosowania, mianem wzorca określa „prawdziwy” buniewski, którym mówiono w przeszłości. Głównym celem

${ }^{21}$ Ich rozwój na tym obszarze był bardzo dynamiczny: od początkowego stwierdzenia, że tworzą jedną wspólnotę z Šokcami, do zupełnego porzucenia pierwiastka šokackiego (założona w 1991 roku partia Bunjevačka i šokačka stranka w roku 2003 zmieniła w związku z tym nazwę na Bunjevačka stranka, a powstałe w 1993 roku czasopismo „Bunjevačke i šokačke novine” od 1998 roku publikowane jest jako „Bunjevačke novine”) i od maksymalistycznych żądań, by Serbia definiowana była jako państwo Serbów i Buniewców, do zgody na status mniejszości narodowej, która w tym kraju nie jest pod żadnym względem uprzywilejowana.

${ }^{22}$ Dotąd ukazał się jeden numer, dostępny pod adresem $<$ http://bunjevackiprigled.wordpress.com/>, 26.06.2013.

${ }^{23}$ Ukazywał się w odcinkach (od 6.11.1998 do 26.08.1999 roku) w czasopiśmie „Bunjevačke novine”, a jego autor podpisywał się pseudonimem Dida Razgala. Tekst jest w całości dostępny na stronie internetowej <http://bunjevci.com/site/bunjevacki-jezik/kako-pisat-bunjevacki/>, 26.06.2013. 
autora jest wyraźne odróżnienie mowy Buniewców od języka oficjalnego (stąd np. z trzech będących w użyciu form 3 osoby liczby mnogiej czasu teraźniejszego czasownika moliti dopuszczone są tylko molu i molidu, podczas gdy forma mole już nie), natomiast zasada „pisz tak, jak się mówiło”, oznacza też surowe egzekwowanie pisowni fonetycznej (np. radijo zamiast radio, pricidnik zamiast pridsidnik, a nawet saš zamiast sad ćeš, co jest odrzuceniem dotychczasowej tradycji piśmiennictwa buniewskiego) oraz konsekwentne unikanie środków właściwych językowi pisanemu (np. jako zamiennik dla szeregu znaczeniowo i funkcjonalnie wyspecjalizowanych spójników i przysłówków proponuje się charakterystyczne dla języka mówionego šta, wskazując, że buniewski nie jest przewidziany do wypełniania wyższych funkcji kulturowych). Buniewskie media i działacze kulturalni w wielu kwestiach stosują zasady głoszone w omawianym artykule, co przynosi paradoksalne skutki. Po pierwsze, ponieważ „właściwy” język buniewski nie zawiera środków językowych do opisu wielu współczesnych zjawisk, są one przejmowane z języka serbskiego, to z kolei często prowadzi do uznawania za język buniewski serbskiego języka standardowego, stylizowanego jedynie na buniewski pod względem fonetycznym i leksykalnym (Vuković 2007: 706). Po drugie, skrajny krytycyzm wobec współczesnych przykładów użycia buniewskiej ikawicy nie motywuje użytkowników do posługiwania się nią, lecz zniechęca i wzmaga powściągliwość Buniewców nie-Chorwatów w posługiwaniu się własnym dialektem.

Tekst Bunjevačka književnost Suzany Kujundžić-Ostojić jest swego rodzaju oficjalnym przeglądem literatury Buniewców ${ }^{24}$; zostały w nim wyróżnione trzy okresy. Pierwszy obejmuje ikawskie piśmiennictwo franciszkańskie, a autorka stara się pokazać bogactwo i znaczenie literatury buniewskiej przed jej rzekomym stłumieniem pod koniec XVIII stulecia, co czyni, pomijając związek tej literatury z szerszą tradycją piśmiennictwa „iliryjskiego" oraz włączając do niej również pisarzy, którzy Buniewcami nie byli, jak np. autora pierwszego kompletnego przekładu Biblii na język „,iliryjski”, pochodzącego ze Slawonii Matiję Petara Katančicia. W okresie drugim, odrodzeniowym, przemilczane zostały dążenia Buniewców zamieszkujących Królestwo Węgier do modernizacji w ramach

${ }^{24}$ Ukazał się na stronie internetowej Rady Narodowej Buniewców (Bunjevačko nacionalno vijeće) $<$ http://www.bunjevci.net/knjizevnost>, 26.06.2013. 
zjednoczenia z chorwacką kulturą narodową, Ivan Antunović zaś przedstawiony jest jako pionier idei buniewskiej tożsamości. Jednocześnie autorka podkreśla znaczenie tych pisarzy, którzy sprzeciwiali się modernizacji, szukając poklasku u prostego czytelnika. W trzecim okresie dominują autorzy „utrąceni”, odrzuceni przez krytykę ze względu na wtórne wykorzystywanie znanej tematyki i próżny sentymentalizm, podczas gdy krytycznie i buntowniczo nastawieni do tradycyjnego dziedzictwa Buniewców pisarze modernistyczni i postmodernistyczni nie zostali nawet wspomniani. Zgodnie z zaprezentowanym w tekście stanowiskiem, na uznanie nie zasługuje literatura otwierająca przed czytelnikami nowe horyzonty, lecz ta, która zamyka ich w starannie ogrodzonym rezerwacie (Vuković 2013).

\section{Zakończenie}

Dwie grupy Buniewców z Bački podchodzą do swego dziedzictwa językowego i kulturowego na dwa znacząco różne sposoby, a co za tym idzie, odmiennie definiują swoje tożsamości. Buniewcy Chorwaci budują swą tożsamość, wykorzystując nurty modernizacyjne własnej tradycji, choć wiele uwagi poświęcając zarazem kulturze ludowej. Czynią to w obrębie współczesnej kultury chorwackiej, uznawanej za spadkobierczynię kultur przednowoczesnych, z którymi ich własna była w przeszłości powiązana najbliżej. Buniewcy nie-Chorwaci swoją tożsamość postrzegają natomiast przez pryzmat idealizowanego wyobrażenia wspólnoty tradycyjnej, w której kultura ma charakter wyłącznie popularny i przenoszona jest głównie ustnie, w kontakcie bezpośrednim. Tak zdefiniowana tożsamość kulturowa nie jest źródłem impulsów modernizacyjnych, dlatego nie-Chorwaci czerpią je z dominującej kultury serbskiej. Dwa opisane modele kształtowania tożsamości całkowicie się rozmijają.

Mimo to, lub może właśnie dlatego, polityczni i kulturalni działacze Buniewców Chorwatów i Buniewców nie-Chorwatów są do siebie skrajnie wrogo nastawieni - uważają się nawzajem za zdrajców tradycji i chętnie odebraliby prawo do niej swoim oponentom ${ }^{25}$. Grupy te wła-

${ }^{25}$ Dobrym przykładem tego stanu rzeczy jest list otwarty czołowych przedstawicieli Buniewców Chorwatów z 2005 roku, w którym żądają oni od władz serbskich, by zaprzestały 
ściwie się ze sobą nie komunikują, a dotychczasowe próby zainicjowania dialogu pochodziły spoza centrum wspólnoty i nie były owocne. W odróżnieniu od spolaryzowanych buniewskich elit, szersze kręgi obu społeczności odnoszą się do siebie mniej nieprzyjaźnie i nie tak jednoznacznie. Jak pokazują wyniki wszystkich dotychczasowych spisów ludności, tylko połowa Buniewców, którzy określili się jako Chorwaci, za swój język uważa chorwacki, pozostali zaś podali ten, którym rzeczywiście posługują się na co dzień, czyli serbski. Wyniki badań socjologicznych z 1996 roku pokazują przy tym, że prawie połowa osób, która na spisie zadeklarowała narodowość buniewską uważa, że Buniewcy są po prostu Chorwatami (Todosijević 2002: 12). Wydaje się, że działacze polityczni i kulturalni po obu stronach muszą dopiero zjednać sobie zwolenników. Może właśnie dlatego ich polemikom towarzyszy tak gorąca atmosfera.

\section{Przełożyła Anna Dudek \\ Weryfikacja ttumaczenia: Magdalena Połczyńska i Krystyna Pieniążek-Marković}

\section{Literatura}

Andrić J., 1988, Nadimak „Rkać” (Rkač), „Etnološka tribina” nr 2, s. 43-58.

Bačić S., Bušić K., Vuković P., 2005, Bunjevci, w: Leksikon podunavskih Hrvata Bunjevaca i Šokaca, red. S. Bačić, t. 4, Subotica, s. 46-70.

Bara M., 2006, Hrvatska seljačka stranka u narodnom preporodu bačkih Hrvata, „Pro tempore" nr 3, s. 59-75.

Čamprag D. (red.), 2007, Zbornik radova sa simpozijuma „O Bunjevcima”, Subotica.

Černelić M., 1995-1996, Comparable occurences in wedding customs of the Bunjevci and Romance language speaking inhabitants of the Balkan peninsula, „Studia Ethnologica Croatica" nr 7-8, s. 181-192.

wspierania instytucjonalizacji odrębnej tożsamości buniewskiej $(<$ http://www.dshv.net/hrvatski/aktuelnosti/aktuelnosti180205.htm>, 26.06.2013) oraz pozew sądowy z 2010 roku, w którym Stowarzyszenie Obywatelskie Bunjevačko kolo z Samoboru (Udruga građana „Bunjevačko kolo") wnosiło o zakaz używania przymiotnika bunjevački przez Chorwackie Centrum Kulturalne Bunjevačko kolo z Suboticy (Hrvatski kulturni centar „Bunjevačko kolo”). Ani pismo, ani pozew nie przyniosły oczekiwanych skutków. 
Černelić M., 2006, Nastojanja da se bačkim Bunjevcima ospori pripadnost hrvatskome narodu, w: M. Černelić, Bunjevačke studije, Zagreb, s. 185-199.

Drugo mišljenje Mađarske akademije znanosti o inicijativi za priznavanje Bunjevaca kao posebne etničko-nacionalne manjine u Mađarskoj, 2011, przeł. Đ. Dragojlović, „Godišnjak za znanstvena istraživanja Zavoda za kulturu vojvođanskih Hrvata" nr 3, s. 275-307.

Erdeljanović J., 1930, O poreklu Bunjevaca, Beograd.

Gavrilović S., 2007, Srpsko-bunjevačka simbioza u Somboru od kraja XVII do sredine XVIII veka, w: Zbornik radova sa simpozijuma „O Bunjevcima”, red. D. Čamprag, S. Kujundžić-Ostojić, Subotica, s. 13-25.

Ivanić I., 1894, O Bunjevcima, Subotica.

Njegomir D., 2008, Dokumenti o nasilnoj hrvatizaciji Bunjevaca i Šokaca u Vojvodini posle Drugog svetskog rata, w: Etnolingvistička i istorijska istraživanja o Bunjevcima, red. M. Pižurica, S. Kujundžić-Ostojić, Subotica, s. 105-112.

Petrović D., 2007, Bački Bunjevci u svetlosti etnoistorijskih lingvističkih činjenica, w: Zbornik radova sa simpozijuma „O Bunjevcima”, red. D. Čamprag, S. Kujundžić-Ostojić, Subotica, s. 115-131.

Pižurica M., Kujundžić-Ostojić S., 2008, Etnolingvistička i istorijska istraživanja o Bunjevcima, Subotica.

Pranjković I., 2000, Hrvatski jezik i franjevci Bosne Srebrene, Zagreb.

Skenderović R. (red.), 2010, Identitet bačkih Hrvata, Zagreb-Subotica.

Skenderović R., 2011, The Franciscan monastery of St. Francis's wounds in Budaa cultural center for the Croats in Hungarian Danube region during the 18 th century, ,Review of Croatian History” nr 1, s. 235-250.

Šarić M., 2008, Bunjevci u ranome novom vijeku: postanak i razvoj jedne predmoderne etnije, w: Živjeti na Krivom Putu. Etnološko-povijesna monografija o primorskim Bunjevcima, t. 1, red. M. Černelić, M. Rajković, T. Rubić, Zagreb, s. 15-42.

Šarić M., 2010, Vlasi na tromeđi - suživot u sukobima u graničnim društvima i kulturama Morlakije (16.-17. stoljeće), (praca doktorska), Zagreb.

Todosijević B., 2002, Why Bunjevci did not become a nation?, „East Central Europe” nr 29, s. 59-72.

Vuković P., 2007, „Bunjevački jezik”-korijeni, varijeteti, perspektive, w: Jezik i identiteti, red. J. Granić, Zagreb-Split, s. 699-710.

Vuković P., 2010, Konstrukcija identiteta u bačkih Bunjevaca, w: Identitet bačkih Hrvata, red. R. Skenderović, Zagreb-Subotica, s. 263-289.

Vuković P., 2011, Dijalektalno pjesništvo u bačkih Bunjevaca, „Godišnjak za znanstvena istraživanja Zavoda za kulturu vojvođanskih Hrvata" nr 3, s. 167-184.

Vuković P., 2013, Veličina osujećenih - književna tradicija za bačke Bunjevce nehrvate, „Nova riječ” $\mathrm{nr} 1$, s. 105-117.

Vuković P., 2014, Jezični program bačkih Bunjevaca nehrvata, w: Bunjevci u vremenskom i prostornom kontekstu, red. M. Černelić, J. Grbić Jakopović, Zagreb (w druku).

Weaver E.B., 2011, Hungarian views of the Bunjevci in Habsburg times and the interwar period, „Balcanica” nr 42, s. 77-115. 
Strony internetowe

$<$ http://www.seebiz.eu/nikolic-porucio-bunjevcima-niste-ni-hrvati-ni-srbi/ar-77197/> $<$ http://godisnjak.zkvh.org.rs/>

$<$ http://bunjevackiprigled.wordpress.com/>

$<$ http://bunjevci.com/site/bunjevacki-jezik/kako-pisat-bunjevacki/>

$<$ http://www.bunjevci.net/knjizevnost $>$

$<$ http://www.dshv.net/hrvatski/aktuelnosti/aktuelnosti180205.htm> 